\title{
Verification of Penetration of Lead in the Profile of Soil around the Former Battery Production Factory, Berat Albania
}

\author{
Mirela Alushllari*, Nikolla Civici \\ Institute of Applied Nuclear Physics, University of Tirana, Tirana, Albania \\ Email: ${ }^{*}$ m.alushllari@gmail.com
}

Received 16 March 2015; accepted 20 April 2015; published 21 April 2015

Copyright (C) 2015 by authors and Scientific Research Publishing Inc.

This work is licensed under the Creative Commons Attribution International License (CC BY).

http://creativecommons.org/licenses/by/4.0/

(c) (i) Open Access

\begin{abstract}
The current study reports the concentration of lead in top of the soil samples and its penetration until the depth of approximately $120 \mathrm{~cm}$. Representative soil samples are collected around the former Factory Production of Batteries to Berat, Albania at a distance 80 - $900 \mathrm{~m}$ from factory. We have chosen 12 sampling points. We have collected a total of 55 samples where 31 were soil samples (12 top of soil and 19 were profile soil samples) and 24 were random vegetation samples. All soil samples were analyzed using Atomic Absorption Spectrometry for their lead content, at the Institute of Applied Nuclear Physics, University of Tirana, Albania. From results obtained the fraction of lead in profile soil samples was in range: $78 \mathrm{mg} / \mathrm{kg}-52,982 \mathrm{mg} / \mathrm{kg}$ and average concentration of lead was $2976 \mathrm{mg} / \mathrm{kg}$, while in random vegetation samples was in range: $0.238-5.573$ $\mathrm{mg} / \mathrm{kg}$. In general, trend of the content of lead in profile soil samples was decreasing compared to the content of lead in the respective top soil samples. The concentrations of lead which have been found in analyzed soil samples are compared with the Maximum Contaminant Levels specified by the Directive 86/278/EEC. Also, we have calculated Hazardous Quoted for each sampling point which is found very high. HQ in representative surface soil samples is $0.4-80.7$ times higher than normal.
\end{abstract}

\section{Keywords}

Lead, Top and Profile Soil Samples, Atomic Absorption Spectrometry

\section{Introduction}

The presence of heavy metals in environment is dangerous because they have tendency to bioaccumulate [1].

${ }^{*}$ Corresponding author.

How to cite this paper: Alushllari, M. and Civici, N. (2015) Verification of Penetration of Lead in the Profile of Soil around the Former Battery Production Factory, Berat Albania. Journal of Environmental Protection, 6, 388-398.

http://dx.doi.org/10.4236/jep.2015.64038 
Also, heavy metals reach the food chain through the supply of drinking water, respiration and food consumption [2] [3]. In addition, lead is known as one of the most toxic heavy metals; it is inclined and tends to be accumulated in the environment [4]. The high level of lead has a negative impact on the natural environment and the human health. The sources of emission of lead in the environment are natural and anthropogenic [5]. Over the years lead is extracted from the mines for different purposes, such as: production of batteries, half-done production of metallic sheets and pipes, alloys, additive in benzene, in polyvinyl chloride, in ammunitions [6]. Since lead is mostly used for the production of batteries, the major pollution comes exactly from this industry. The exposure to lead in the environment results in a wide range of negative effects, depending from the level of lead and time of extended. The high levels of exposure to $\mathrm{Pb}$ result in biochemical and toxic effects on the people [7]. The environmental protection should be and remain the main goal and task of the society. The purpose of this study is: a) Estimate and impact of the industrial waste of lead in the profile of soil around the territory of the former Factory of Battery Production, Berat, Albania and b) determination of lead in random vegetation as well as calculation of determinate bioaccumulation factor soil to plant. This factory has begun its activity in 1970 (about 20 years) and it was designed to produce batteries for passengers' cars and trucks and technical equipment. One of the methods for determination of the total contents of heavy metals of their environmental concentrations is AAS. In this paper we present determination of lead in soil by AAS method. The level of $\mathrm{Pb}$ in soil samples was compared to the values recommended by the European Community according to Directive 86/278 EEC and the potential of risk HQ was calculated by USEPA, while for biological samples level of lead was compared by Directive No. 1881/2006, Brussels [8]-[10]. We have calculated the bioaccumulation factor soil to plant.

\section{Material and Method}

All representative soil samples are collected into and around the former Battery Production Factory, Berat. This Factory is located in the northeastern city of Berat, with respective coordinate: $400^{\circ} 42^{\prime} 24.82^{\prime \prime} \mathrm{N}$ and $190^{\circ} 58^{\prime} 59.42$ "E. During the sampling we have chosen 12 stations and we have collected a total 31 samples where 19 were profile soil samples in this region. Representative soil samples are collected at the top of soil (0 $5 \mathrm{~cm}$ ) while profile soil sample are collected in depth $15-120 \mathrm{~cm}$. These sampling stations are marked in map Figure 1, while their coordinates are presented respectively in Table 1 with results. All soil samples are analyzed using Atomic Absorption Spectrometer, Aanalyst 800 Perkin Elmer with Atomic Absorption Spectrometry, Flame method PE [11]. Hollow cathode lamp used as radiation source for the determination of Pb according recommended conditions. Acids used for the digestion of samples, stock solutions of lead have high grade purity. Glass and Teflon vessels used were treated with solution $10 \% \mathrm{v} / \mathrm{v}$ nitric acid, for 24 hours and then washed with water bidistilled. Instrumental conditions for lead are based on AMAAS, from PE [11]. Three applications were carried out for the measurement of calibration standards and measurement of samples. For each element calibration curve equation is linear and passing through point zero. A quality control material IAEA-Soil_7 was analyzed in parallel with the soil samples and IAEA_336 Lichen was analyzed in parallel with the biological samples. To check the instrumental drift, an aqueous standard solution was analyzed after every three samples.

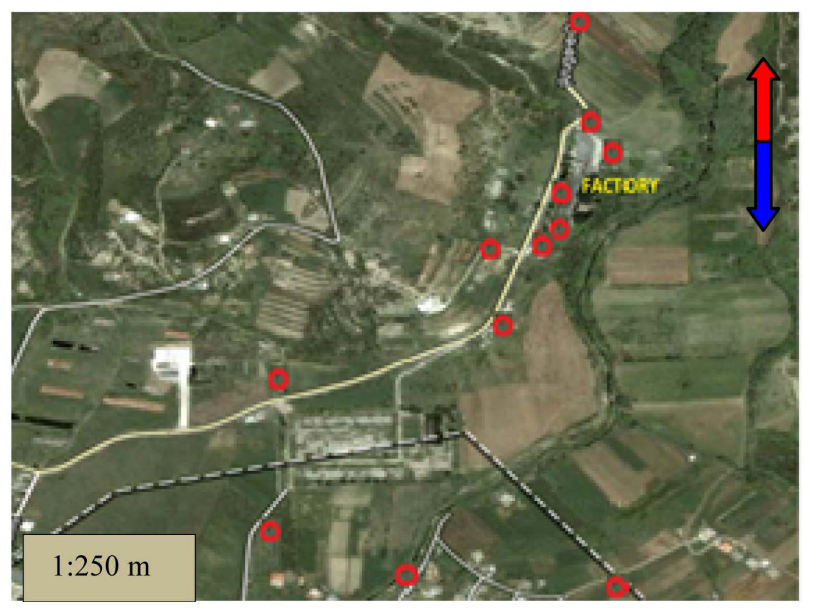

Figure 1. Map of sampling stations of soil. 
Table 1. The concnetration of lead in both CRM soil and vegetation.

\begin{tabular}{ccccccc}
\hline Element & Type of CRM & Value of CRM mg/kg & Pb mg/kg & SD & RSD\% & Recovery\% \\
\hline $\mathrm{Pb}$ & IAEA-Soil-7 & $60 \pm 8$ & 56.8 & 2.8 & 5.7 & 94.9 \\
$\mathrm{~Pb}$ & IAEA_336_Lichen & $4.9 \pm 0.6$ & 4.1 & 0.23 & 8.97 & 83.7 \\
\hline
\end{tabular}

Note: $(n=3)$.

\subsection{Digestion of Soil Samples}

About 0.5 gram of dry soil sample was placed in a digestion tube and was added $10 \mathrm{ml}$ of aqua regia $\left(1 \mathrm{HNO}_{3}: 3\right.$ $\mathrm{HCl}$ ). The sample was heated for $30-35 \mathrm{~min}$ at $90^{\circ} \mathrm{C}$, and then the temperature was increased to $180^{\circ} \mathrm{C}$ at which the sample was boiled for at least 2 - 3 hour until a clear solution was obtained. Concentrated $\mathrm{HNO}_{3}$ was added to the sample, $9 \mathrm{ml}$ was added at least three times and digestion occurred until the volume was reduced to about 1 - 2 ml. The interior walls of the tube were washed down with a little bidistilled water and the tube was swirled throughout the digestion to keep the wall clean and prevent the loss of the sample. After cooling, $5 \mathrm{ml}$ of $2 \%$ $\mathrm{HNO}_{3}$ was added to the sample. It was then transferred quantitatively to a $50 \mathrm{ml}$ volumetric flask by adding distilled water. And finally the solution was filtered.

\subsection{Digestion of Biological Samples}

Each dry vegetation sample was weighed and was added a $10 \mathrm{ml} \mathrm{HNO}_{3}$ solution. For the wet digestion process, an 8 hour period of digestion was provided at room temperature. After this time cold digestion period, the glass beakers were placed on a hot plate and heated for about 1 - 2 hour. Then, 1 ml hydrogen peroxide $\left(\mathrm{H}_{2} \mathrm{O}_{2}\right)$ was added to each beaker and the beakers were heated again until the wet digestion process was completed and a small sample volume remained. It was then transferred quantitatively to a $50 \mathrm{ml}$ volumetric flask by adding distilled water. And finally the solution was filtered; their solutions were transferred to the atomic absorption lab for analysis.

\section{Results and Discussions}

For the accuracy of the analytical procedure for the determination of lead in environmental representative soil and vegetation samples are using certified reference material. Specifically for soil samples was used IAEA Soil-7, while for vegetation samples was used 336 IAEA. Standard reference material samples were attended the same digestion procedure with the nature of the respective sample group. In Table 1 is presented the results obtainned form analyzed CRM for content of lead in soil and vegetation, SD, \% RSD and \% R. In Table 2 is presented, sampling points, code in AAS, coordinates, mean concentration of lead in soil samples, \% RSD and SD in representative top and profile soil samples. In addition, from results obtained of soil samples we have calculated HQ (US EPA 2006) [10] for representative surface soil samples. In Table 3 is presented, sampling points, code in AAS, coordinates, mean concentration of lead in vegetation samples, SD and calculated bioaccumulation factor soil to plant in representative top soil samples. From results obtained it was observed the concentration of lead there is not unique distribution. The highest concentration of lead was found in samples which are collected in S_1 and S_14 points. By analyzing profile samples in these points the lead concentration was higher than surface. These sampling points have been selected close the factory, because in this area there are industrial solid waste thrown uncontrollably, into the environment. The Concentration of lead in the top of soil was found in the order $78 \mathrm{mg} / \mathrm{kg}-24,207 \mathrm{mg} / \mathrm{kg}$ and average concentration of lead was $3523 \mathrm{mg} / \mathrm{kg}$. While the concentration of lead in profile soil samples was found in this ranged $125 \mathrm{mg} / \mathrm{kg}-52,982 \mathrm{mg} / \mathrm{kg}$ and average concentration of lead was $5614 \mathrm{mg} / \mathrm{kg}$. The concentrations of lead in representative soil samples are compared with the MCL specified by the Directive 86/278/EEC. Maximal concentration of lead in soil recommended by the Directive 86/278/EEC is 300 (mg/kg) and was calculated HQ by USEPA. Factor of HQ was found in order 0.3 - 81. If the calculated factor of HQ in soil samples is higher than 1, than the territory is contaminated and this pollution is associated with high negative ecological and human effects. In vegetation samples the concentration of lead was found in this ranged: $0.238-5.573 \mathrm{mg} / \mathrm{kg}$. The presence of lead in biological samples is high. Level of lead in vegetation samples are compared with the MCL specified by the Directive No. 1881/2006, Brussels. The dates of Table 2 \& Table 3 are presented in the graphical forms as below. Graph in Figure 2 is presented the 
Table 2. Mean concentration of lead in the both top and profile soil samples.

\begin{tabular}{|c|c|c|c|c|c|c|c|c|}
\hline Nr. & Sampling point & Code in AAS & Material & Nord & East & $\mathrm{Pb}$ (mg/kg) & SD & $\%$ RSD \\
\hline 1 & S_1 & $\mathrm{P} 1 \mathrm{~T} 1$ & Surface soil & $40^{\circ} 42^{\prime} 21.32^{\prime \prime}$ & $19^{\circ} 58^{\prime} 56.74 "$ & 3008 & 33.09 & 1.10 \\
\hline 2 & S_1 & $\mathrm{P} 1 \mathrm{~T} 2$ & Profile & $40^{\circ} 42^{\prime} 21.32^{\prime \prime}$ & $19^{\circ} 58^{\prime} 56.74 "$ & 3052 & 82.41 & 2.70 \\
\hline 3 & S_2 & $\mathrm{P} 2 \mathrm{~T} 1$ & Surface & $40^{\circ} 42^{\prime 2} 21.61^{\prime \prime}$ & $19^{\circ} 58^{\prime} 57.63^{\prime \prime}$ & 5663 & 7.36 & 0.13 \\
\hline 4 & S_2 & P2 T2 & Profile & $40^{\circ} 42^{\prime} 21.61^{\prime \prime}$ & $19^{\circ} 58^{\prime} 57.63^{\prime \prime}$ & 4789 & 76.62 & 1.60 \\
\hline 5 & S_2 & Р2 Т3 & Profile & $40^{\circ} 42^{\prime} 21.61^{\prime \prime}$ & $19^{\circ} 58^{\prime} 57.63^{\prime \prime}$ & 4741 & 37.93 & 0.80 \\
\hline 6 & S_4 & P4 T1 & Surface soil & $40^{\circ} 42^{\prime} 24.18^{\prime \prime}$ & $19^{\circ} 58^{\prime} 58.01 "$ & 5511 & 22.04 & 0.40 \\
\hline 7 & S_4 & P4 T2 & Profile & $40^{\circ} 42^{\prime} 24.18^{\prime \prime}$ & $19^{\circ} 58^{\prime} 58.01^{\prime \prime}$ & 821 & 15.59 & 1.90 \\
\hline 8 & S_4 & P4 T3 & Profile & $40^{\circ} 42^{\prime} 24.18^{\prime \prime}$ & $19^{\circ} 58^{\prime} 58.01^{\prime \prime}$ & 196 & 7.25 & 3.70 \\
\hline 9 & S_4 & $\mathrm{P} 4 \mathrm{~T} 4$ & Profile & $40^{\circ} 42^{\prime} 24.18^{\prime \prime}$ & $19^{\circ} 58^{\prime} 58.01^{\prime \prime}$ & 135 & 3.78 & 2.80 \\
\hline 10 & S_5 & P5_T1 & Surface & $40^{\circ} 42^{\prime} 22.08^{\prime \prime}$ & $19^{\circ} 58^{\prime} 55.57^{\prime \prime}$ & 397 & 3.00 & 0.75 \\
\hline 11 & S_5 & P5_T2 & Profile & $40^{\circ} 42^{\prime} 22.08^{\prime \prime}$ & $19^{\circ} 58^{\prime} 55.57^{\prime \prime}$ & 424 & 19.93 & 4.70 \\
\hline 12 & S_5 & P5_T3 & Profile & $40^{\circ} 42^{\prime} 22.08^{\prime \prime}$ & $19^{\circ} 58^{\prime} 55.57^{\prime \prime}$ & 354 & 13.45 & 3.80 \\
\hline 13 & S_6 & P6_T1 & Surface & $40^{\circ} 42^{\prime} 15.54^{\prime \prime}$ & $19^{\circ} 58^{\prime} 53.06^{\prime \prime}$ & 856 & 24.81 & 2.90 \\
\hline 14 & S_6 & P6_T2 & Profile & $40^{\circ} 42^{\prime} 15.54^{\prime \prime}$ & $19^{\circ} 58^{\prime} 53.06^{\prime \prime}$ & 334 & 12.37 & 3.70 \\
\hline 15 & S_6 & P6_T3 & Profile & $40^{\circ} 42^{\prime} 15.54^{\prime \prime}$ & $19^{\circ} 58^{\prime} 53.06^{\prime \prime}$ & 352 & 29.23 & 8.30 \\
\hline 16 & S_7 & P7_T1 & Surface soil & $40^{\circ} 42^{\prime} 14.45^{\prime \prime}$ & $19^{\circ} 58^{\prime} 53.43^{\prime \prime}$ & 333 & 19.32 & 5.80 \\
\hline 17 & S_7 & P7_T2 & Profile & $40^{\circ} 42^{\prime} 14.45^{\prime \prime}$ & $19^{\circ} 58^{\prime} 53.43^{\prime \prime}$ & 277 & 26.91 & 9.70 \\
\hline 18 & S_7 & P7_T3 & Profile & $40^{\circ} 42^{\prime} 14.45^{\prime \prime}$ & $19^{\circ} 58^{\prime} 53.43^{\prime \prime}$ & 199 & 2.79 & 1.40 \\
\hline 19 & S_14 & P14_T1 & Surface soil & $40^{\circ} 42^{\prime} 27.26^{\prime \prime}$ & $19^{\circ} 58^{\prime} 59.67^{\prime \prime}$ & 24,207 & 11.00 & 18.00 \\
\hline 20 & S_14 & P14_T2 & Profile & $40^{\circ} 42^{\prime} 27.26^{\prime \prime}$ & $19^{\circ} 58^{\prime} 59.67^{\prime \prime}$ & 26,142 & 0.06 & 11.00 \\
\hline 21 & S_14 & P14_T3 & Profile & $40^{\circ} 42^{\prime} 27.26^{\prime \prime}$ & $19^{\circ} 58^{\prime} 59.67^{\prime \prime}$ & 52,982 & 9.90 & 3.80 \\
\hline 22 & S_15 & P15_T1 & Surface soil & $40^{\circ} 42^{\prime} 33.45^{\prime \prime}$ & $19^{\circ} 58 " 57.86^{\prime \prime}$ & 350 & 3.00 & 5.60 \\
\hline 23 & S_15 & P15_T2 & $\begin{array}{l}\text { Erosion } \\
\text { profile }\end{array}$ & $40^{\circ} 42^{\prime} 33.45^{\prime \prime}$ & $19^{\circ} 58^{\prime} 57.86^{\prime \prime}$ & 125 & 14.00 & 11.20 \\
\hline 24 & S_28 & P28_T1 & $\begin{array}{c}\text { Erosion } \\
\text { profile }\end{array}$ & $40^{\circ} 42^{\prime} 24.45^{\prime \prime}$ & $19^{\circ} 59^{\prime} 00.96^{\prime \prime}$ & 78 & 0.20 & 0.10 \\
\hline 25 & S_28 & P28_T2 & Surface soil & $40^{\circ} 42^{\prime} 26.21^{\prime \prime}$ & $19^{\circ} 59^{\prime} 01.29^{\prime \prime}$ & 10,614 & 3.00 & 0.60 \\
\hline 26 & S_31 & S31_T1 & Surface soil & $40^{\circ} 42^{\prime} 06.07^{\prime \prime}$ & $19^{\circ} 58^{\prime} 43.86^{\prime \prime}$ & 185 & 2.70 & 1.46 \\
\hline 27 & S_31 & S31_T2 & Profile & $40^{\circ} 42^{\prime} 06.07^{\prime \prime}$ & $19^{\circ} 58^{\prime} 43.86^{\prime \prime}$ & 218 & 13.50 & 6.19 \\
\hline 28 & S_33 & S33_T1 & Profile & $40^{\circ} 42^{\prime} 08.00^{\prime \prime}$ & $19^{\circ} 58^{\prime} 52.31^{\prime \prime}$ & 1503 & 3.21 & 0.21 \\
\hline 29 & S_33 & S33_T2 & Profile & $40^{\circ} 42^{\prime} 08.00^{\prime \prime}$ & $19^{\circ} 58^{\prime} 52.31 "$ & 718 & 6.43 & 0.90 \\
\hline 30 & S_37 & S37_T1 & Surface soil & $40^{\circ} 42^{\prime} 05.09^{\prime \prime}$ & $15^{\circ} 58^{\prime} 59.73^{\prime \prime}$ & 187 & 16.30 & 8.72 \\
\hline 31 & S_37 & S37_T2 & Profile & $40^{\circ} 42^{\prime \prime 05.09 "}$ & $15^{\circ} 58^{\prime} 59.73^{\prime \prime}$ & 193 & 8.90 & 4.61 \\
\hline
\end{tabular}

mean concentration of lead in top of soil samples, while graph in Figure 3 is presented the probability plot of lead concentration. Graph in Figure 4 is presented contour plot of lead concentration in top of soil samples, while graph in Figure 5 is presented the mean concentration of lead in surface and profile soil samples, comparison of lead content in surface with profile soil samples. A graph in Figure 6 is presented the calculated HQ for lead in top soil samples, while the graph in Figure 7 is presented the dependence of the distribution of lead in different distance from the factory $(0-800 \mathrm{~m})$. Graph in Figure 8 is presented the mean concentration of lead in top of soil and vegetation samples, their concentration comparison, while graph in Figure 9 is presented the probability plot of lead concentration in vegetation samples. Graph in Figure 10 is presented contour plot of lead concentration in vegetation samples, while graph in Figure $\mathbf{1 1}$ is presented the relationship between lead concentration in surface soil samples and lead concentration in the vegetation samples. A graph in Figure 12 is 
Table 3. Mean concentration of lead in vegetation samples and BAF soil to plant.

\begin{tabular}{|c|c|c|c|c|c|c|c|c|}
\hline Nr. & $\begin{array}{l}\text { Sampling } \\
\text { point }\end{array}$ & $\begin{array}{l}\text { Code in } \\
\text { AAS }\end{array}$ & Material & Nord & East & $\mathrm{Pb}$ (mg/kg) & SD & $\mathrm{BAF} \times 10^{3}$ \\
\hline 1 & S_1 & P1_BS & Cynadon dactiyon & $40^{\circ} 42^{\prime} 21.32^{\prime \prime}$ & $19^{\circ} 58^{\prime} 56.74^{\prime \prime}$ & 3.226 & 2.09 & 1.07 \\
\hline 2 & S_2 & P2_BS & Cynadon dactiyon & $40^{\circ} 42^{\prime 2} 21.61^{\prime \prime}$ & $19^{\circ} 58^{\prime} 57.63 "$ & 3.501 & 1.36 & 0.62 \\
\hline 3 & S_2 & P2_PN & Pinus pinea & $40^{\circ} 42^{\prime} 21.61^{\prime \prime}$ & $19^{\circ} 58^{\prime} 57.63 "$ & 2.227 & 1.98 & 0.39 \\
\hline 4 & S_4 & P3_BS & Verbascum (sp) & $40^{\circ} 42^{\prime} 24.18^{\prime \prime}$ & $19^{\circ} 58^{\prime} 58.01^{\prime \prime}$ & 1.519 & 2.04 & 0.28 \\
\hline 5 & S_4 & P3_PN & Pinus pinea & $40^{\circ} 42^{\prime} 24.18^{\prime \prime}$ & $19^{\circ} 58^{\prime} 58.01^{\prime \prime}$ & 3.437 & 3.00 & 0.62 \\
\hline 6 & S_4 & P3_PT & Pinus pinea & $40^{\circ} 42^{\prime} 24.18^{\prime \prime}$ & $19^{\circ} 58^{\prime} 58.01 "$ & 3.829 & 4.81 & 0.69 \\
\hline 7 & S_5 & P5_F & Ficus carica & $40^{\circ} 42^{\prime} 22.08^{\prime \prime}$ & $19^{\circ} 58^{\prime} 55.57^{\prime \prime}$ & 1.034 & 9.32 & 2.60 \\
\hline 8 & S_5 & P5_BS & Verbascum (sp) & $40^{\circ} 42^{\prime} 22.08^{\prime \prime}$ & $19^{\circ} 58^{\prime} 55.57^{\prime \prime}$ & 2.042 & 3.53 & 5.14 \\
\hline 9 & S_6 & P6_BS & Cynadon dactiyon & $40^{\circ} 42^{\prime} 15.54^{\prime \prime}$ & $19^{\circ} 58 " 53.06 "$ & 2.125 & 5.12 & 2.48 \\
\hline 10 & S_6 & P6_F & Ficus carica & $40^{\circ} 42^{\prime} 15.54^{\prime \prime}$ & $19^{\circ} 58^{\prime} 53.06^{\prime \prime}$ & 0.859 & 2.64 & 1.00 \\
\hline 11 & S_6 & P6_H & Diospiros (sp) & $40^{\circ} 42^{\prime} 15.54^{\prime \prime}$ & $19^{\circ} 58^{\prime} 53.06^{\prime \prime}$ & 1.207 & 1.67 & 1.41 \\
\hline 12 & S_6 & P6_V & Ulmus canpestris & $40^{\circ} 42^{\prime} 15.54^{\prime \prime}$ & $19^{\circ} 58^{\prime} 53.06^{\prime \prime}$ & 1.141 & 1.61 & 1.33 \\
\hline 13 & S_6 & P6_L & Euphorbia (sp) & $40^{\circ} 42^{\prime} 15.54^{\prime \prime}$ & $19^{\circ} 58^{\prime} 53.06^{\prime \prime}$ & 1.134 & 0.67 & 1.33 \\
\hline 14 & S_6 & P6_BS & Cynadon dactiyon & $40^{\circ} 42^{\prime} 15.54^{\prime \prime}$ & $19^{\circ} 58^{\prime} 53.06^{\prime \prime}$ & 2.375 & 1.27 & 2.77 \\
\hline 15 & S_7 & P7_BS & Verbascum (sp) & $40^{\circ} 42^{\prime} 14.45^{\prime \prime}$ & $19^{\circ} 58^{\prime} 53.43^{\prime \prime}$ & 1.337 & 0.34 & 4.02 \\
\hline 16 & S_7 & P7_L & Euphorbia (sp) & $40^{\circ} 42^{\prime} 14.45^{\prime \prime}$ & $19^{\circ} 58^{\prime} 53.43^{\prime \prime}$ & 0.994 & 8.21 & 2.98 \\
\hline 17 & S_14 & P14_BS & Cynadon dactiyon & $40^{\circ} 42^{\prime} 27.26^{\prime \prime}$ & $19^{\circ} 58^{\prime} 59.67 "$ & 2.186 & 0.28 & 0.09 \\
\hline 18 & S_14 & P14_BT & Verbascum (sp) & $40^{\circ} 42^{\prime} 27.26^{\prime \prime}$ & $19^{\circ} 58^{\prime} 59.67^{\prime \prime}$ & 4.093 & 2.14 & 0.17 \\
\hline 19 & S_15 & P15_BS & Cynadon dactiyon & $40^{\circ} 42^{\prime} 33.45^{\prime \prime}$ & $19^{\circ} 58^{\prime} 57.86^{\prime \prime}$ & 0.927 & 1.97 & 2.65 \\
\hline 20 & S_28 & P28_BT & Verbascum (sp) & $40^{\circ} 42^{\prime} 26.21^{\prime \prime}$ & $19^{\circ} 59^{\prime} 01.29^{\prime \prime}$ & 4.572 & 2.73 & 0.46 \\
\hline 21 & S_31 & P32_HN & Triticum aestivum & $40^{\circ} 42^{\prime \prime} 06.07 "$ & $19^{\circ} 58^{\prime} 43.86^{\prime \prime}$ & 0.824 & 1.64 & 4.45 \\
\hline 22 & S_33 & P34_PN & Pinus pinea & $40^{\circ} 42^{\prime} 04.11^{\prime \prime}$ & $19^{\circ} 58^{\prime} 03.79^{\prime \prime}$ & 0.642 & 0.43 & 0.43 \\
\hline 23 & S_33 & P34_PN & Pinus pinea & $40^{\circ} 42^{\prime \prime 04.11 "}$ & $19^{\circ} 58^{\prime} 03.79^{\prime \prime}$ & 0.451 & 3.14 & 0.30 \\
\hline 24 & S_37 & P37_G & Triticum aestivum & $40^{\circ} 42^{\prime} 05.09^{\prime \prime}$ & $15^{\circ} 58^{\prime} 59.73^{\prime \prime}$ & 0.238 & 1.19 & 1.27 \\
\hline
\end{tabular}

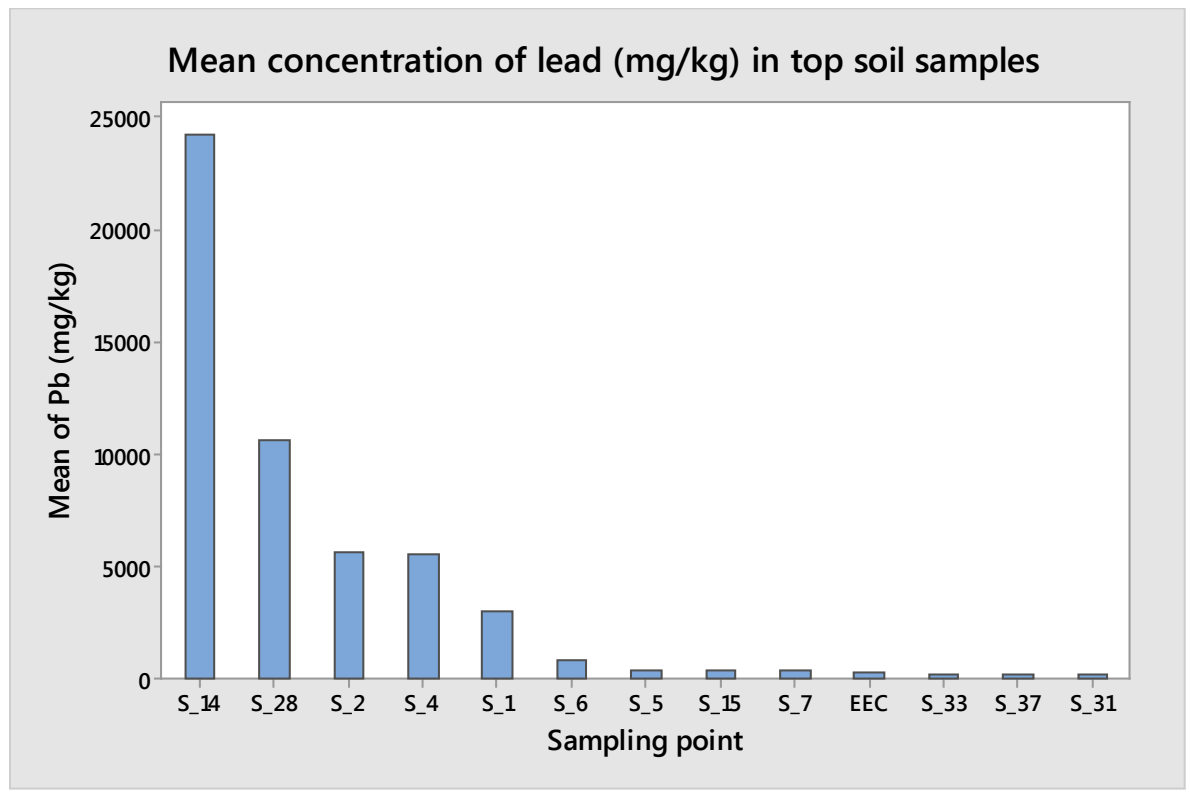

Figure 2. Concentration of lead in top of soil. 


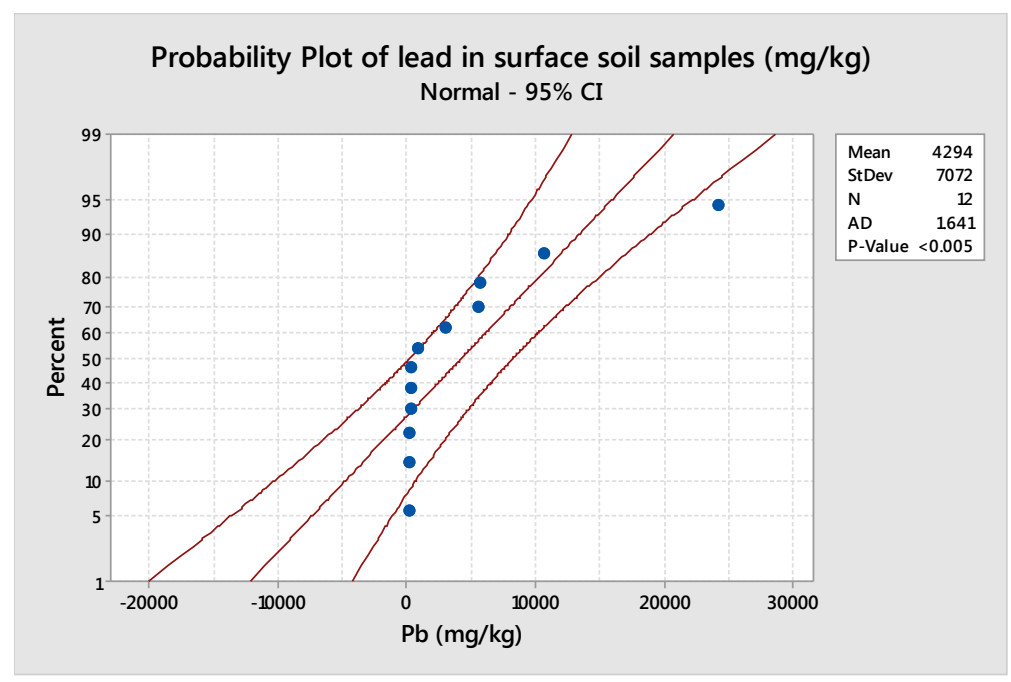

Figure 3. Probability plot of lead in top soil (mg/kg).

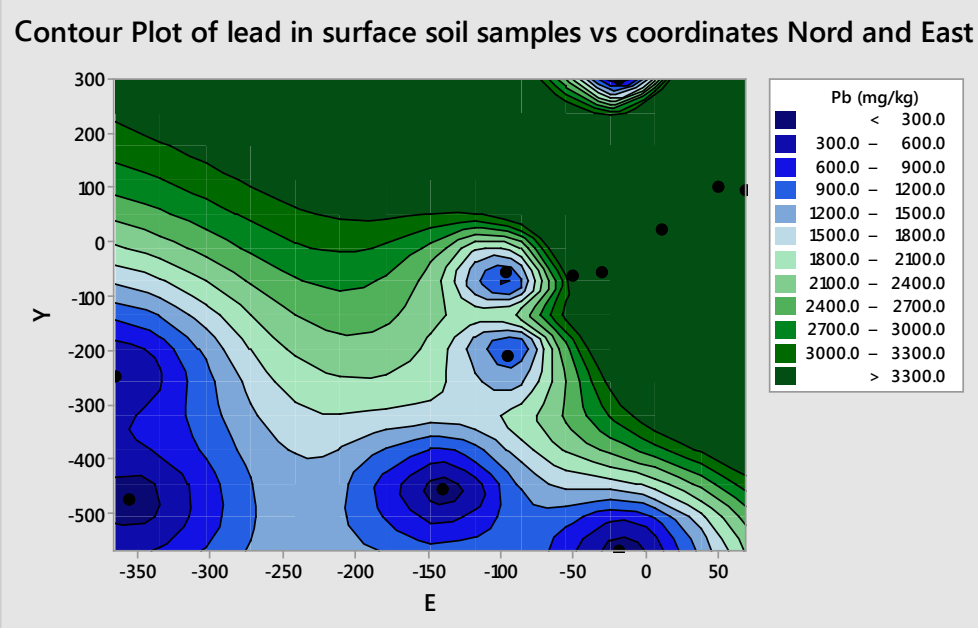

Figure 4. Contour plot of lead in top of soil.

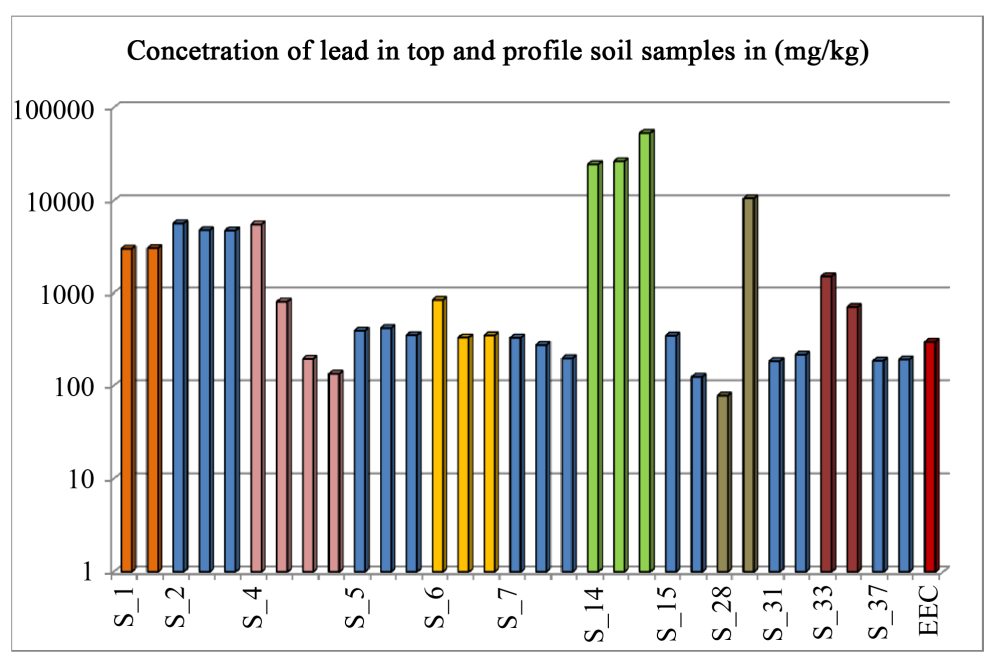

Figure 5. Comparison of lead in surface and profile soil. 


\section{Factor of Hazardous Quoted for top soil samples}

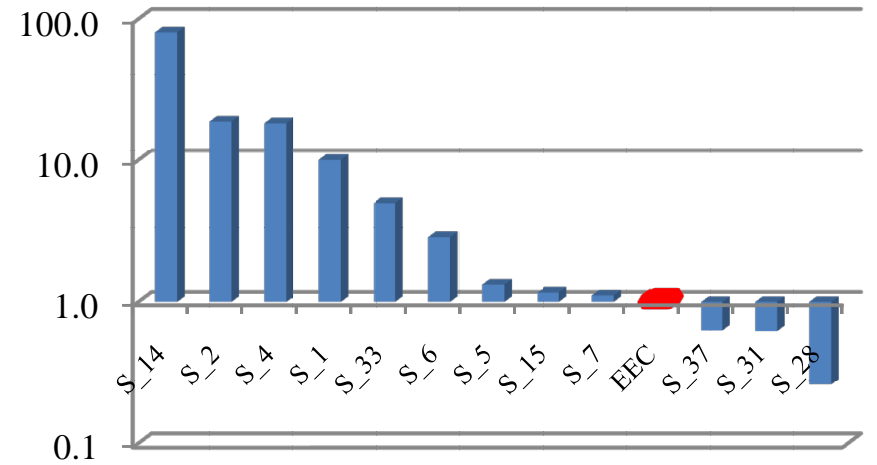

Figure 6. Calculated Hazardous Quoted of lead.

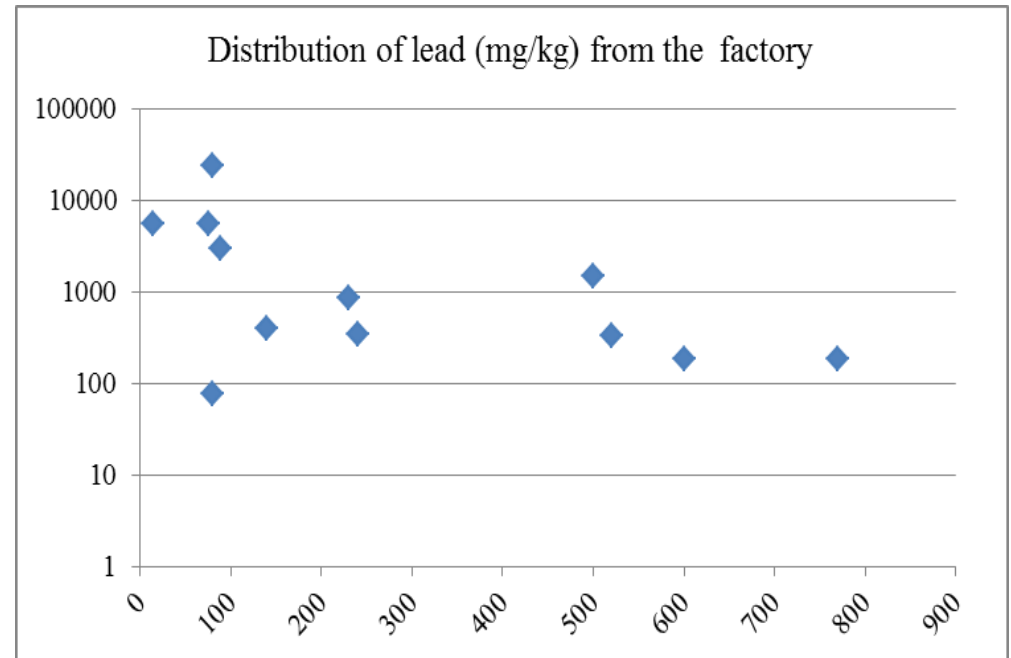

Figure 7. Dependence of lead in distance from factory.

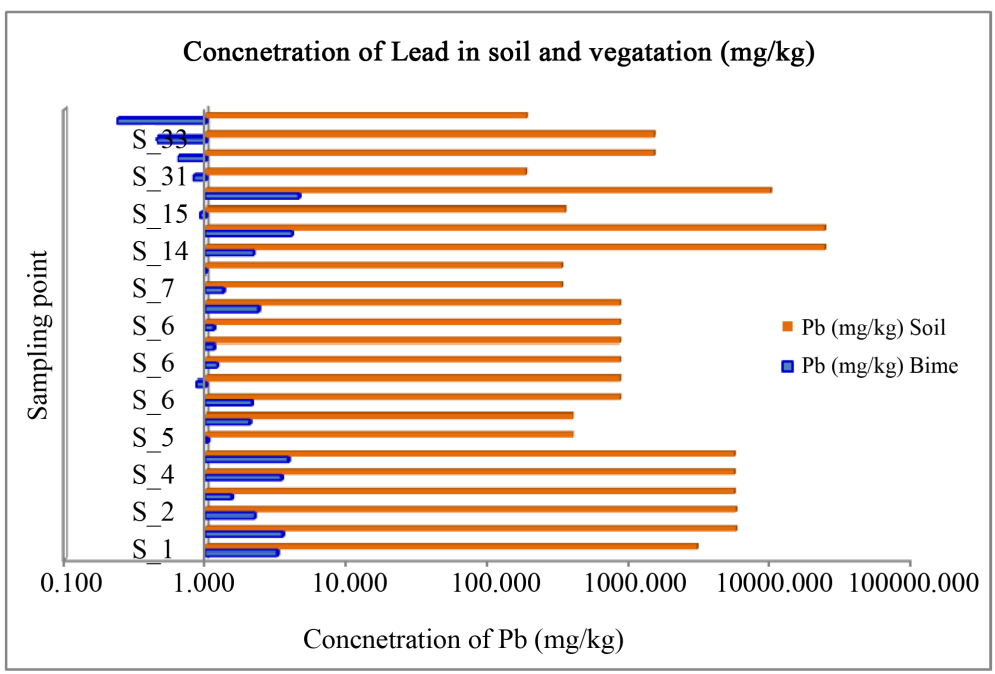

Figure 8. Concentration of lead in soil and vegetation. 


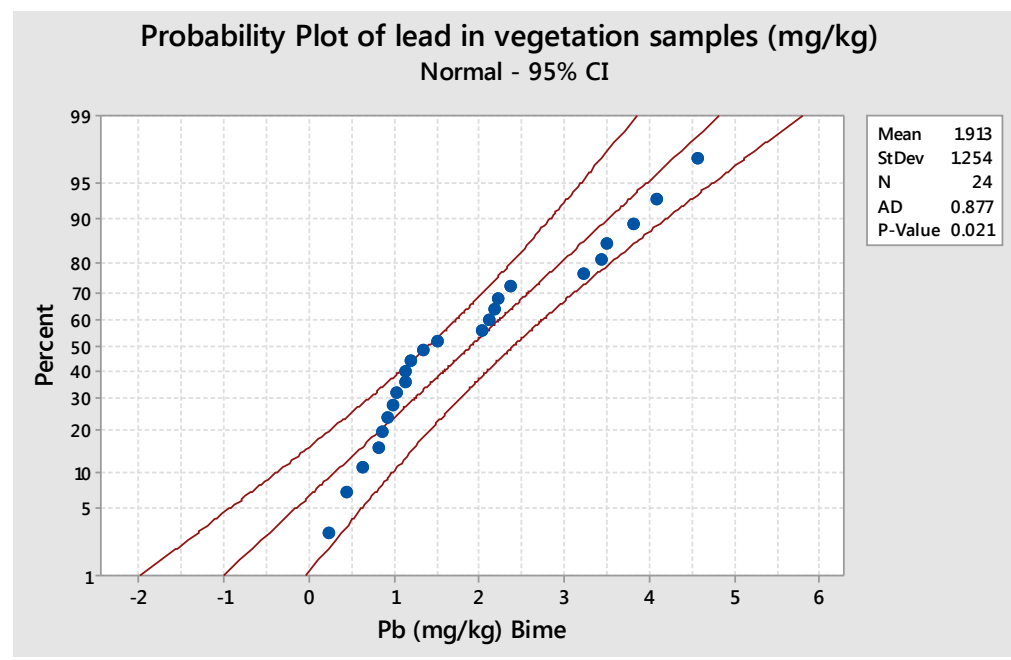

Figure 9. Probability plot of lead in vegetation.

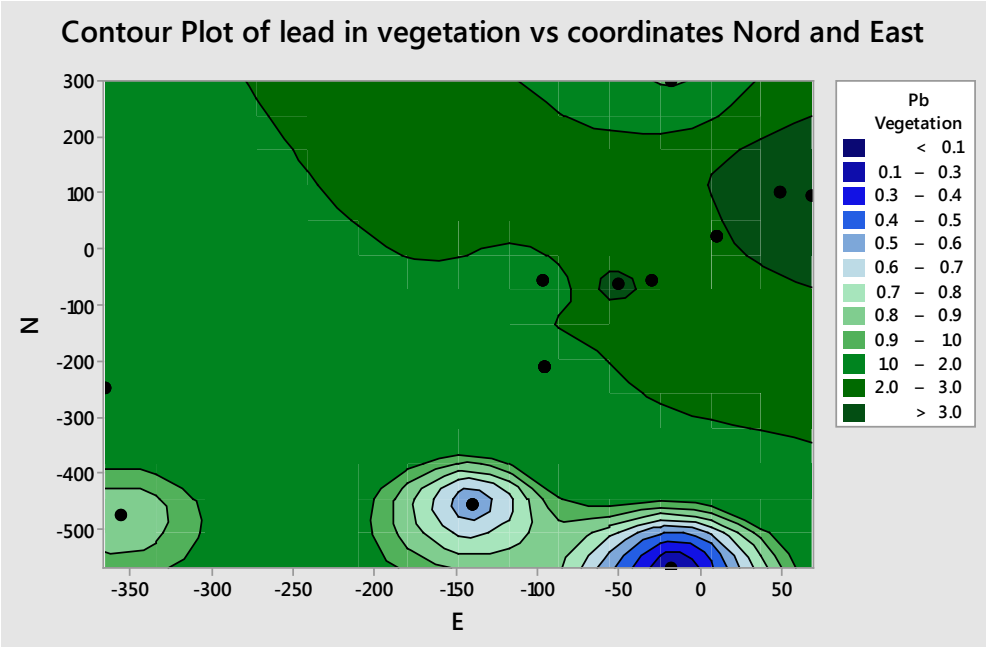

Figure 10. Contour plot of lead vegetation.

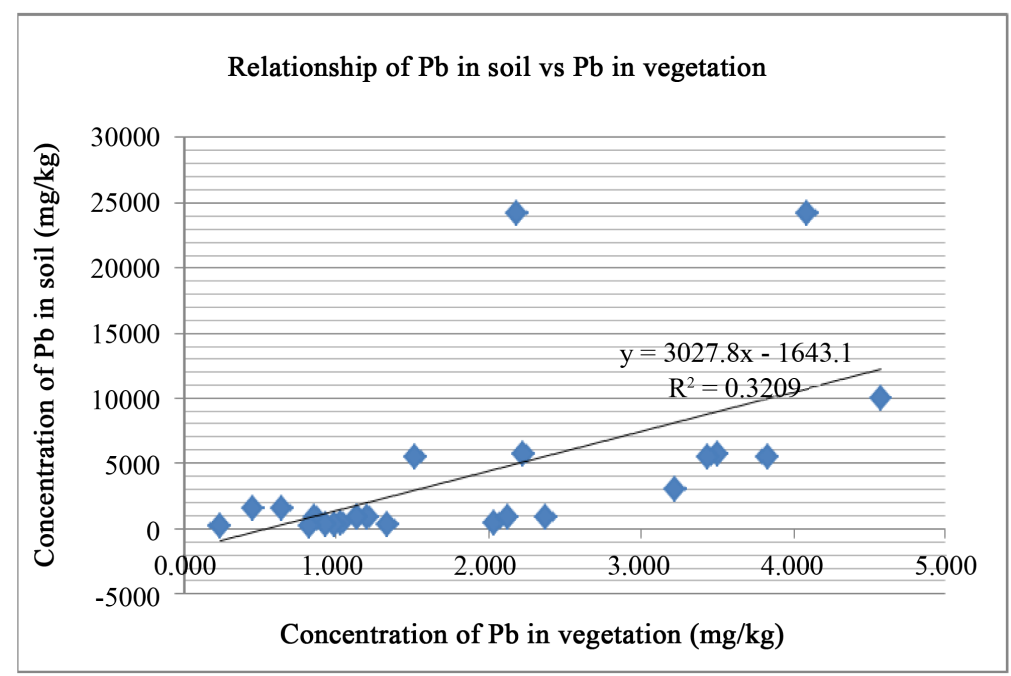

Figure 11. Dependence of lead in distance from factory. 


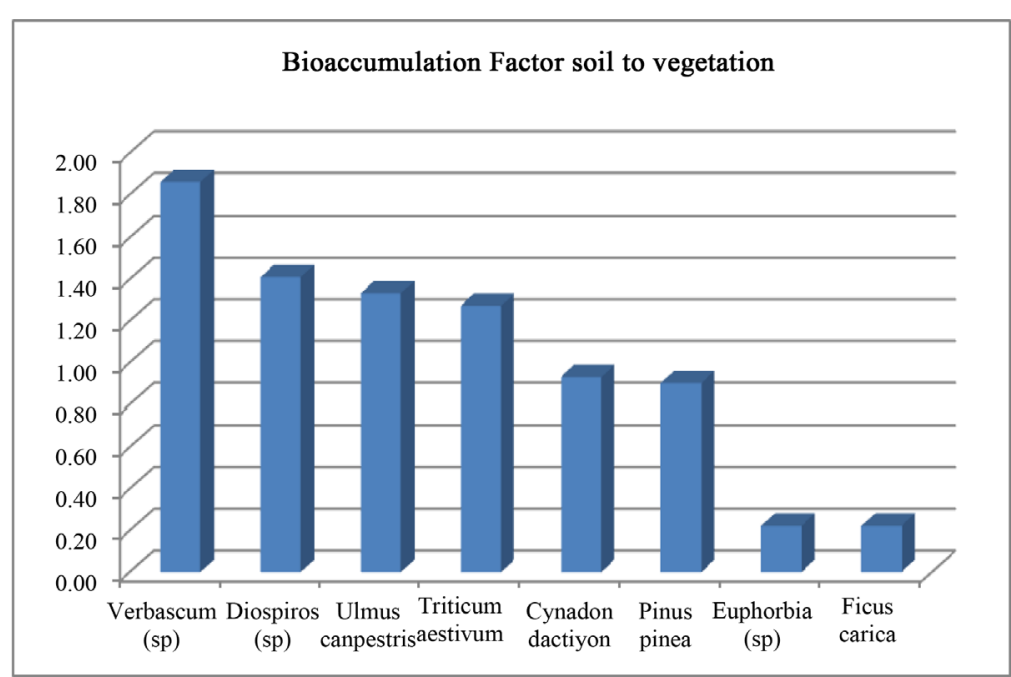

Figure 12. The calculated bioaccumulation factor.

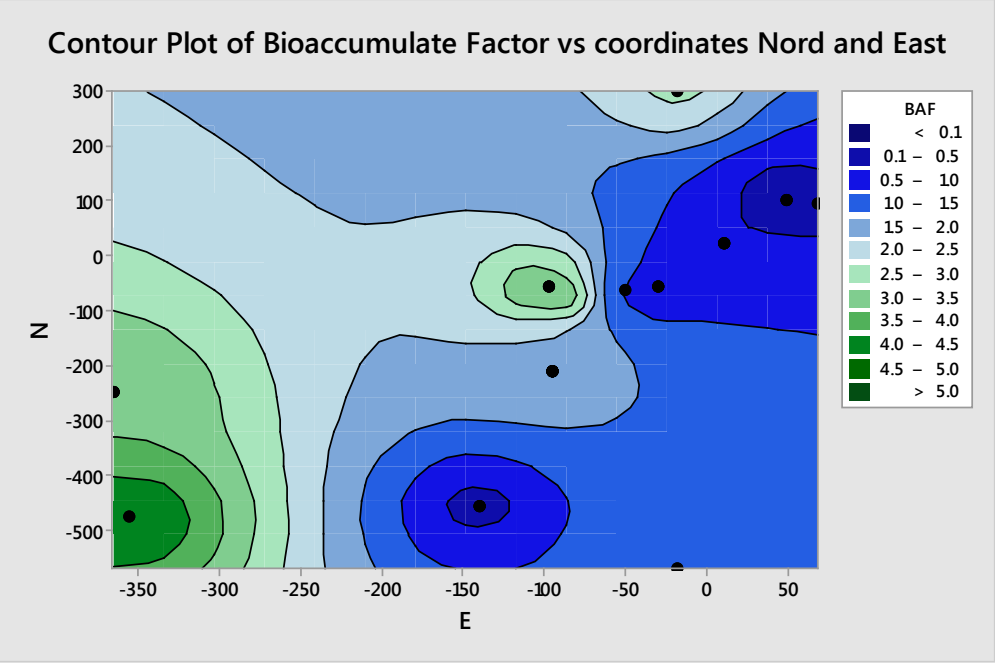

Figure 13. Counter plot of BAF.

presented the calculated BAF soil to plant, while the graph in Figure 13 is presented counter plot of calculated BAF soil to plant versus coordinates, Nord and East.

\subsection{Tables}

Measurements obtained after analyzing CRM, soil and vegetation samples for determining the fraction of lead are presented in Tables 1-3.

\subsection{Figures}

The dates of Table 2 and Table 3, the concnetration of lead in soil and vegetation which are found in respectively samples are presented in the graphical forms.

\section{Conclusions}

This paper presents the verification of distribution of lead concentration in the surface soil and its penetration in the profile soil samples. Lead was found present in all the soil samples. By comparing the concentration of lead in surface soil samples with MCL recommended by Directive 86/278/EEC, only three of the soil samples con- 
tained lead below this concentration. The highest level of lead was found in soil samples which have been selected close the factory, S14 and S28. It was observed the lead concentration in the profile soil samples was found much higher than the level of lead in respective top soil samples. Industrial solid wastes are disposal uncontrollably, into the environment, in territory close to the factory. Thus the concentration of lead in profile soil samples (S14 and S28) was found higher than the surface soil samples for the reason that solid waste from factory were mixed with soil. Also the highest level of lead was found in top soil samples which were collected inside the factory, but in profile soil the lead has trend to decrease. Area where samples are collected is not used to cultivate plant crops but the random vegetation is used like livestock feed from inhabitants. Also, it was observed that distribution of lead depending of distance from factory is decrease, in the distance about $400-500 \mathrm{~m}$ from the factory. The bioaccumulation factor soil to plant was found in low values because the mean concentration of lead in soil was found very high. BFA depends on many factors like: the concentration of lead in soil and vegetation, duration of exposure, $\mathrm{pH}$ of soil, bioaccumulation ability of plants, atmospheric conditions, etc. By calculating the average of BAF soil to plant it is observed lead accumulates in plants at different levels. The ability of lead accumulation by random vegetation in descending order was: Verbascum $(s p)>$ Diospiros $(s p)>$ Ulmus canpestris $>$ Triticum aestivum $>$ Cynadon dactiyon $>$ Pinus pinea $>$ Euphorbia $(s p)>$ Ficus carica.

The presence of lead in high concentration in representative soil samples was contributed by industrial waste as a result of the activity of the factory for about 20 years and waste disposal uncontrollably in the surrounding environment. From results obtained for concentration range of lead in soil samples collected at the area around the former Battery Production Factory, sometimes it can be observed that the measured concentrations are much higher than the MCL specified by EEC. High concentrations of lead and its duration in the environment have impacted negatively the ecosystem and human health.

\section{Acknowledgements}

This work is part of my thesis of PhD. My appreciation is send to Institute of Applied Nuclear Physics; to Faculty of Natural Sciences, University of Tirana and to my Family. Thank you for your endless support.

\section{References}

[1] Censi, P., Spoto, S.E., Saiano, F., Sprovieri, M., Mazzola, S., Nardone, G., Di Geronimo, S.I., Punturo, R. and Ottonello, D. (2006) Heavy Metals in Coastal Water System. Chemosphere, 64, 1167-1176. http://dx.doi.org/10.1016/j.chemosphere.2005.11.008

[2] Gazso, L.G. (2001) The Key Microbial Processes in the Removal of Toxic Metals and Radionuclides from the Environment. A Review. Central European Journal of Occupational and Environmental Medicine, 7, 178-185.

[3] Marmiroli, N. (2003) Accumulation of Copper and Zinc from Liquid Manure in Agricultural Soils and Crop Plants. Plant and Soil, 250, 249-257.

[4] Zayed, A., Lytle, C.M., Qian, J.H. and Terry, N. (1998) Chromium Accumulation, Translocation and Chemical Speciation in Vegetable Crops. Planta, 206, 293-299. http://dx.doi.org/10.1007/s004250050403

[5] Carpenter, S.R., Caraco, N.F., Correll, D.L., Howarth, R.W., Sharpely, A.N. and Smith, V.H. (1998) Nonpoint Pollution of Surface Waters With Phosphorus and Nitrogen, Ecological Applications, 8, 559-568. http://dx.doi.org/10.1890/1051-0761(1998)008[0559:NPOSWW]2.0.CO;2

[6] Demayo, A., Taylor, M.C., Taylor, K.W. and Hodson, P.V. (1982) Toxic Effects of Lead and Lead Compounds on Human Health, Aquatic Life, Wildlife Plants, and Livestock. Critical Reviews in Environmental Control, 12, $257-305$. http://dx.doi.org/10.1080/10643388209381698

[7] Aigbedion, L.N. (2005) Environmental Pollution in the Niger Delta, Nigeria. Inter Disciplinary Journal Enugu Niger, 3, 205-210.

[8] EEC, Economic European Communities (2006) The Council Directive 86/278/EEC on Protection of the Environment.

[9] EEC, Economic European Communities (2006) Setting Maximum Levels for Certain Contaminants in Foodstuffs. Official Journal European Communities, L 364/5-L 364/24, Directive No. 1881/2006, Brussels.

[10] U.S. EPA. (Environmental Protection Agency) (2006) Risk Assessment Guidance for Superfund Volume I: Human Health Evaluation Manual (Part E, Supplemental Guidance for Dermal Risk Assessment), Final. EPA/540/R/99/005. Office of Solid Waste and Emergency Response, Washington, DC. PB99-963312.

[11] (Perkin-Elmer Corperation. 1991-1999) Perkin-Elmer Corp.: 1964-2000, Analytical Methods for Atomic Absorption Spectrophotometry \& Recommended conditions for THGA furnaces. 


\section{Abbreviations}

AAS (Atomic Absorption Spectrometry); AAS_GF (Atomic Absorption Spectrometry Graphite Furnace); AMAAS (Analytical Methods of Atomic Absorption Spectrometry); BAF (bioaccumulation factors); CRM (Certified Reference Material); EEC (European Economic Community); HQ (Hazardous Quoted); MCL (Maximum Contaminant Levels); Pb (lead); PE (Perkin Elmer); (\% R) Recovery percentage; \% RSD (Relative Standard Deviation); SD (Standard Deviation); USEPA (United States Environmental Protection Agency). 